\title{
PENERAPAN TEKNOLOGI WEB SEKOLAH BAGI SMP DAN SMA MUHAMMADIYAH KARTASURA
}

\author{
Heru Supriyono ${ }^{1}$, Anam Sutopo ${ }^{2}$, Hamdani Nursyahid ${ }^{3}$, Bryan Anthony Kurniawan ${ }^{3}$, \\ Irfan Nur Fahrudin, Donny Handoko, Imam Rivai, Dwi Cahyo Kurniawan \\ Program Studi Teknik Elektro - Fakultas Teknik \\ Program Pendidikan Bahasa Inggris - Fakultas Keguruan dan Ilmu Pendidikan \\ Program Studi Informatika - Fakultas Komunikasi dan Informatika \\ Universitas Muhammadiyah Surakarta \\ Email : Heru.Supriyono@ums.ac.id
}

\begin{abstract}
Observation and interview with headmasters, teachers and administrative employees results showed that one of main problems faced by SMP Muhammadiyah 1 Kartasura and SMA Muhammadiyah 4 Kartasura is the do not have a representative school website. Based on this observation, after making discussion with headmasters, the community services team proposed an implementation of school website and train one of chosen teacher to manage implemented website. The outcomes of the community service activities are involving a school website for SMP Muhammadiyah 1 Kartasura and SMA Muhammadiyah 4 Kartasura and scientific publication draft. The contribution of each school is including providing information which will be uploaded to the website, providing fee for domain and hosting cost, and providing facilities for administrator training. The duration of this commuity services is three months. The results of the community services is both SMP Muhammadiyah 1 Kartasura dan SMA Muhammadiyah 4 Kartasura are now have representative website for their promotion and administative activities.
\end{abstract}

Kata kunci: Teknologi website sekolah, SMP Muhammadiyah, SMA Muhammadiyah.

\section{PENDAHULUAN}

Seiring dengan perkembangan teknologi, teknologi informasi dan kmputer merupakan fasilitas yang sangat penting untuk menunjang pengelolaan administrasi maupun proses belajar mengajar (PBM). Dalam bidang manaajemen, komputer menyediakan berbagai fasilitas untuk meningkatkan kualitas pelayanan seperti website sekolah untuk sumber informasi antara sekolah dan masyarakat maupun sistem informasi berbasi web untuk menunjang admistrasi data sekolah. Dizaman teknologi seperti saat ini, peran website sekolah adalah seperti sebuah jendela dimana orang diseluruh dunia bisa mengetahui semua informasi tentang sekolah tersebut. Sekolah yang tidak mempunyai web hanya akan dikenal oleh orang-orang yang tinggal disekitar sekolah tersebut.

Sekolah Menengah Pertama (SMP) Muhammadiyah 1 Kartasura, Sukoharjo 
adalah salah satu sekolah dibawah naungan Muhammadiyah. SMP Muhammadiyah 1 Kartasura berdiri tanggal 1 Februari 1949, lokasinya terletak di Dukuh Kemasan Desa Ngadirejo kecamatan Kartasura. Gedung sekolah yang saat ini ditempati memiliki tempat yang sangat strategis yaitu di tepi jalan raya antara Surakarta dan Kartasura yaitu tepatnya di Jalan Achmad Yani 160 Kartasura yang dapat dengan mudah dijangkau oleh guru, karyawan dan siswa. Gedung SMP Muhammadiyah 1 Kartasura ini berdiri di atas tanah seluas kurang lebih 2000 meter persegi yang terletak di desa Sedahromo Kecamatan Kartasura. Status tanah dan gedung adalah milik Yayasan Muhammadiyah. Gedung tersebut berdiri atas 2 bangunan lama, satu lantai dan bangunan dua lantai, berbentuk leter U, ditambah satu bangunan baru, satu lantai. Sekolah ini saat ini memperoleh akeditasi B. SMP Muhammadiyah 1 Kartasura saat ini mempunyai fasilitas pembelajaran berupa 15 ruang kelas, mushola, kantor guru dan karyawan, perpustakaan, laboratorium komputer, dan halaman yang biusa untuk bermain futsal, bola voli, dan bulu tangkis. Jumlah guru di SMP Muhammadiyah 1 Kartasura totalnya sebanyak 24 orang guru dengan kualifikasi pendidikan sarjana (S1) sesuai dengan mata pelajaran yang diampu. Jumlah total siswa dari kelas VII - IX adalah sekitar 450 siswa. Dari hasil observasi didapatkan bahwa sebenarnya SMP Muhammadiyah 1 Kartasura sudah mempunyai sebuah website namun sifatnya masih sangat sederhana yang berisi sekedar company profile saja (http:// smpmutukartasura.blogspot.com/) dengan desain yang belum tertata, fitur yang tidak lengkap dan bahkan banyak fitur yang sudah ada tidak bisa diakses. Website tersebut masih menggunakan framework gratisan blogspot dari Google. Dengan website yang kurang memadai, maka apabila masyarakat luas terutama calon murid dan orangtuanya tidak bisa mendapatkan informasi lengkap mengenai SMP Muhammadiyah 1 Kartasura termasuk prestasi dan capaiannya. Tampilan website SMP Muhammadiyah 1 Kartasura yang sudah ada dapat dilihat pada Gambar 1 .

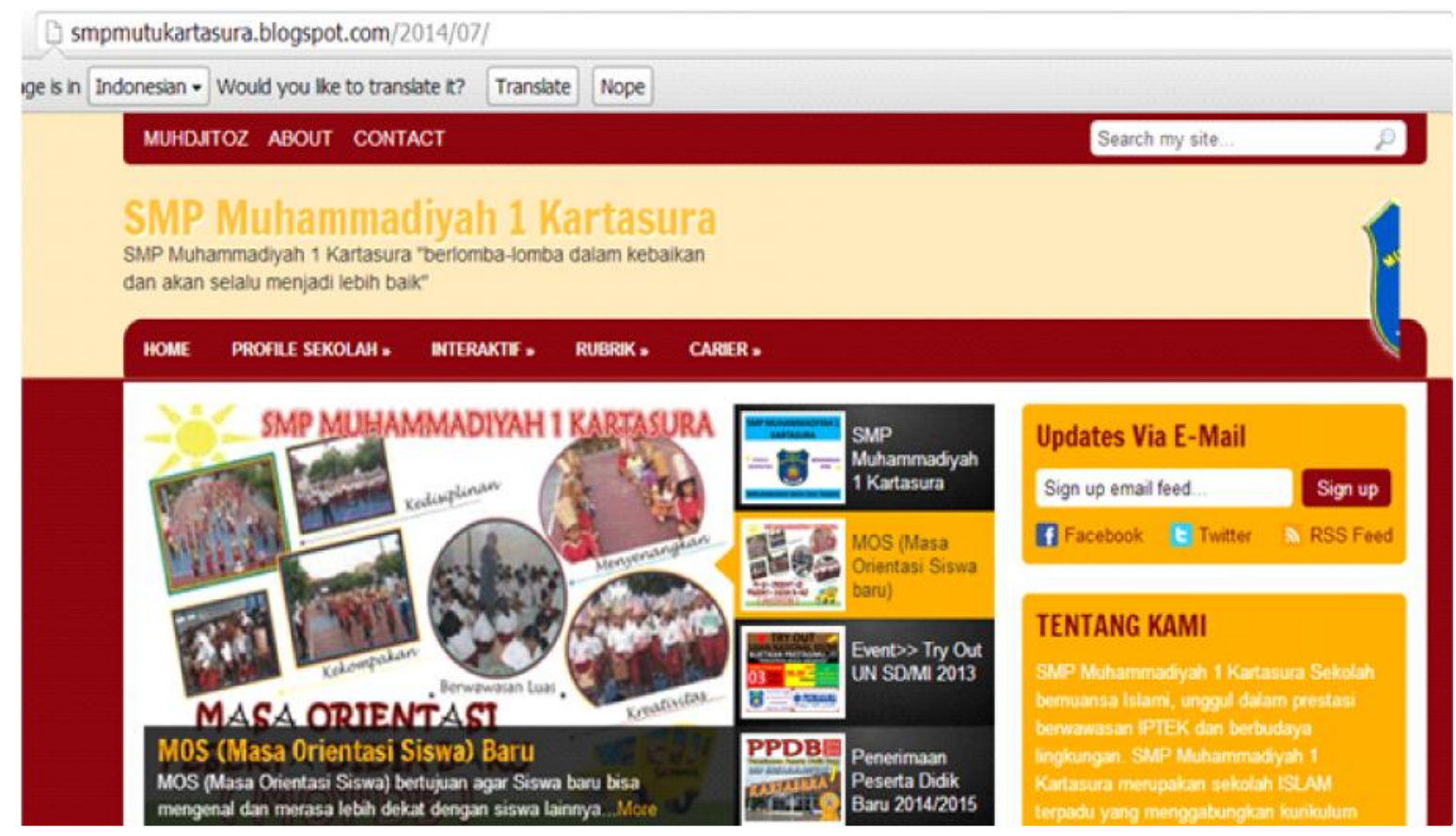

Gambar 1. Tampilan halaman Home website SMP Muhammadiyah 1 Kartasura yang lama 
Sekolah Menengah Atas (SMA) Muhammadiyah 4 Kartasura saat ini mempunyai total 6 kelas untuk siswa kelas X-XII dengan jumlah siswa total sekitar 120 siswa. SMA Muhammadiyah 4 Kartasura saat ini menempati gedung sendiri yang terletak ditepi jalan Kartasura-Sukoharjo dengan alamat Jalan Slamet Riyadi No. 80 Kartasura dengan fasilitas pendukung diantaranya perpustakaan, laboratorium komputer, kantor guru dan karyawan, masjid serta halaman untuk bermain/olahraga. Jumlah guru yang mengajar totalnya ada 13 guru dengan kualifikasi pendidikan sarjana (S1). SMA Muhammadiyah 4 Kartasura belum memiliki website sekolah sehingga menyebabkan masyarakat yang membutuhkan informasi mengenai SMA Muhammadiyah 4 Kartasura harus datang ke sekolah untuk mendapatkannya.

Berdasarkan hasil observasi dengan mendatangi lokasi sekolah dan hasil wawancara dengan kepala sekolah, staf administrasi dan beberapa orang guru, permasalahan yang dapat diidentifikasi pada kedua mitra adalah belum adanya web sekolah yang memadai. Belum adanya website sekolah yang memadai menyebabkan profil dan informasi mengenai fasilitas dan informasi terkini seperti prestasi siswa dan sekolah kurang diketahui oleh masyarakat luas terutama orang tua siswa dan orang tua calon siswa baru. Selama ini sekolah mengenalkan profil sekolahnya melalui leaflet-leaflet yang dibagikan ke masyarakat yang berada disekitar lokasi sekolah atau yang berjarak dalam radius maksimum $8 \mathrm{~km}$. Pengenalan dengan cara ini akan menyebabkan informasi yang diketahui oleh masyarakat hanya terbatas saja karena terbatasnya ukuran leaflet. Adanya website sekolah akan membuat masyarakat luas tanpa dibatasi faktor geografis dapat mengetahui profil lengkap sekolah yang bisa dilengkapi dengan foto maupun video kapan saja tanpa harus datang ke lokasi sekolah.

\section{Pengertian Website}

Website atau lebih dikenal dengan web saja sebuah laman dijaringan internet yang berfungsi menyimpan dan menampilkan informasi. Kelebihan web dinadingkan media cetak adalah web dapat diakses dimanapun pengguna berada tanpa ada batasan tempat asalkan ada akses internet dengan piranti komputer pribadi (personal computer/PC), komputer jinjing/laptop maupun telepon genggam cerdas/ smartphone. Untuk dapat mengakses sebuah laman web, piranti-piranti tersebut harus mempunyai peramban internet (web browser) seperti Mozilla Firefox, Microsoft Internet Explorer, Apple Safari dan Google Chrome. Pengaksesan laman web dilakukan dengan cara memasukkan alamat web laman pada kotak alamat (address bar) pada peramban internet yang ada yang biasanya mempunyai format dengan www.alamatweb.com Atau http;// alamat.webku.com.

\section{Perangkat Lunak Penyusun Website}

Beberapa perangkat lunak utama penyusun sebuah website diantaranya adalah web server, server basis, dan perangkat lunak pengembangan atau bahasa pemrograman. Sebuah web server, contohnya adalah Apache, mempunyai fungsi untuk melayani permintaan pengguna dan kemudian menghubungkannya dengan server basisdata, contohnya adalah MySQL, yang fungsi utamanya adalah menyimpan semua data. Bahasa pemrograman yang digunakan dalam membuat sebuah web adalah hypertext markup language (HTML) dan personal home page (PHP) (Graham, 1995). Versi HTML dan PHP selalu berkembang menyesuaikan perkembangan teknologi dan perkembangan terkini adalah sebuah web sekarang dibuat dengan memanfaatkan 
campuran berbagai fasilitas pengembangan web seperti PHP, HTML5, cascading style sheet (CSS), Java Script (Grannel dkk, 2011; Holzschlag, 2004; Willard, 2010).

1. Tujuan

Tujuan dilaksanakannya kegiatan ini adalah untuk menyediakan sebuah template website sekolah mitra yang sudah dionlinekan yang dapat digunakan untuk media promosi sekolah

2. Manfaat

Manfaat dari terlaksananya kegiatan ini adalah: (i) diperolehnya template webite sekolah yang sudah dionlinekan untuk SMP Muhammadiyah 1 Kartasura dan SMA Muhammadiyah 4 Kartasura sebagai media promosi dan pengenalan SMP Muhammadiyah 1 Kartasura dan SMA Muhammadiyah 4 Kartasura kepada masyarkat, (ii) adanya seorang guru yang sudah dilatih untuk menjadi administrator website sekolah yang bisa mengelola website sekolah, (iii) bagi Program Studi Teknik Elektro dan Informatika Universitas Muhammadiyah Surakarta(UMS), kegiatan ini merupakan salah satu upaya untuk kerjasama dan memperkenalkan Program Studi Teknik Elektro dan Informatika UMS kepada masyarakat dan (iv) bagi tim pelaksana kegiatan ini merupakan wahana untuk mengaplikasikan dan menyebarkan hasil kegiatan penelitian untuk digunakan oleh masyarakat luas.

\section{METODE PELAKSANAAN KEGIATAN}

\section{Kerangka Pemecahan Masalah}

Permasalahan yang dihadapi oleh sekolah mitra akan diselesaikan dengan empat langkah yaitu: (i) pendampingan proses pembuatan template website yang sesuai dengan kebutuhan masing-masing mitra (ii) pendampingan proses pembelian domain website sekolah standar untuk sekolah yaitu dengan domain sch.id dan proses peng-online-an atau hosting, (iii) pendampingan proses instalasi perangkat lunak pendukung untuk administrator pengelola website, (iv) pelatihan guru/ karyawan pada masing-masing sekolah mitra untuk menjadi administrator yang akan diberi tugas untuk mengelola website sekolah yang sudah dibuat. Template website sekolah yang sudah disiapkan dapat diupdate dan dikelola untuk menunjang pengenalan dan promosi SMP Muhammadiyah 1 Kartasura dan SMA Muhammadiyah 4 Kartasura.

\section{Tahapan Pelaksanaan Kegiatan}

Kegiatan pengabdian kepada masayarakat ini akan dilaksanakan dengan tahapan sebagai berikut:

a. Tahap I: observasi dan identifikasi permasalahan. Pada tahap ini tim pelaksana melakukan kunjungan dan wawancara dengan kepala sekolah mengenai adanya website sekolah dan adanya guru yang mempunyai latar belakang pendidikan komputer dan yang mempunyai kemampuan untuk membuat dan mengelola sebuah website sekolah.

b. Tahap II: pendampingan analisis kebutuhan meliputi menentukan rancangan tampilan website, menu-menu website, perangkat lunak dan perangkat lunak yang dibutuhkan.

c. Tahap III: pendampingan penyiapan template website. Pada tahap ini tim pelaksana pengabdian akan melibatkan kepala sekolah atau guru yang ditunjuk sebagai prospective user sehingga website yang dibuat sesuai dengan filosofi dan kebutuhan sekolah.

d. Tahap IV: pendampingan proses pembelian domain website sekolah standar untuk sekolah yaitu dengan domain sch.id dan proses peng-onlinean atau hosting.

e. Tahap V: pendampingan proses instalasi perangkat lunak pendukung untuk administrator pengelola website. 
f. Tahap VI: Pelatihan guru/karyawan pada masing-masing sekolah mitra untuk menjadi administrator yang akan diberi tugas untuk mengelola website sekolah yang sudah dibuat.

\section{Evaluasi Pelaksanaan Kegiatan}

Evaluasi keberhasilan kegiatan pengabdian masyarakat dilakukan dengan memonitor perkembangan website sekolah yang sudah dionlinekan dan digunakan oleh sekolah secara berkala apakah berjalan dengan baik atau masih ada permasalahan. Apabila sudah ada update dari guru/ karyawan sebagai administrator yang sudah dilatih menunjukkan bahwa kegiatan pengabdian kepada masyarakat ini berhasil.

\section{Kebutuhan Perangkat}

Dalam pelaksanaan pengabdian kepada masyarakat ini diperlukan perangkat utama yang meliputi perangkat keras dan perangkat lunak serta perangkat penunjang meliputi: laptop atau komputer untuk perancangan dan pembuatan template website, perangkat lunak untuk pengembangan website meliputi perangkat lunak web server dan database server xampp, laptop yang digunakan untuk pelatihan guru yang ditunjuk untuk menjadi administrator pengelola website, LCD proyektor untuk menampilkan materi dari laptop instruktur dan alat tulis, jaringan internet di sekolah untuk pengelolaan website sekolah secara online.

\section{Proses pendampingan penyiapan template website}

Prose perancangan website sekolah di SMP Muhammadiyah 1 Kartasura dan SMA Muhammadiyah 4 Kartasura pada dasarnya sama namun pada akhirnya tampilan, menu navigasi dan fitur-fitur website yang dibuat berbeda karena masingmasing sekolah mempunyai kebutuhan fitur dan tampilan website sekolah sendiri-sendiri. Penulis membuat rancangan website menggunakan aplikasi Balsamiq Mockup free edition. Gambar rancangan dasar desain website sekolah mitra dapat dilihat pada Gambar 2. 


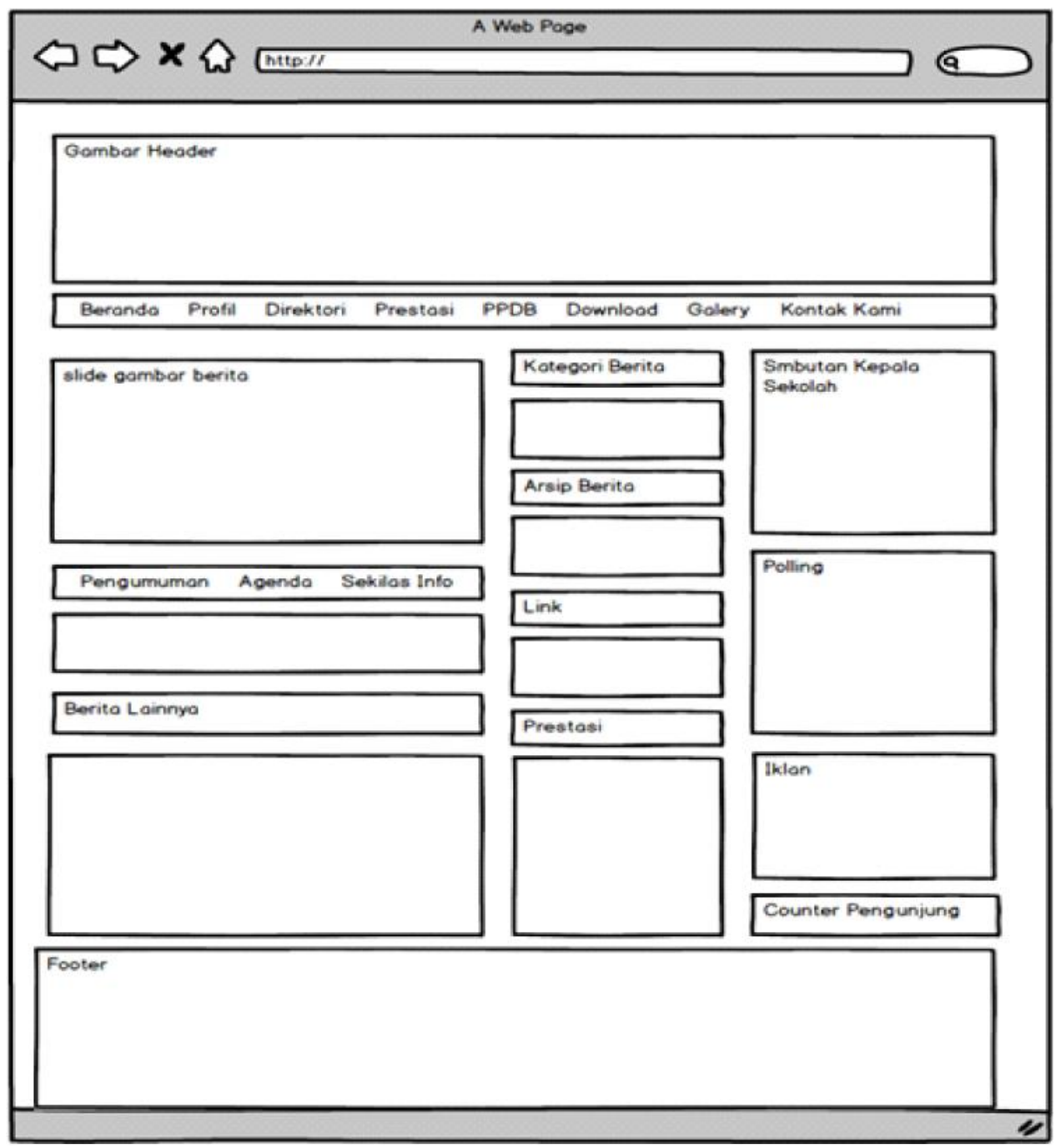

Gambar 2. Rancangan tampilan Halaman Utama

Website yang dibuat mempunyai dua buah jenis pengguna yaitu pengguna biasa dan administrator. Pengguna biasa adalah semua orang umum yang mengunjungi website sedangkan administrator adalah guru yang ditunjuk sebagai peneglola yang mempunyai hak atau kemampuan untuk mengedit, menambah atau menghapus konten website. Hak akses baik untuk administrator dan user biasa dinyatakan dalam use case diagram yang dapat diluhat pada Gambar 3 dan Gambar 4. 


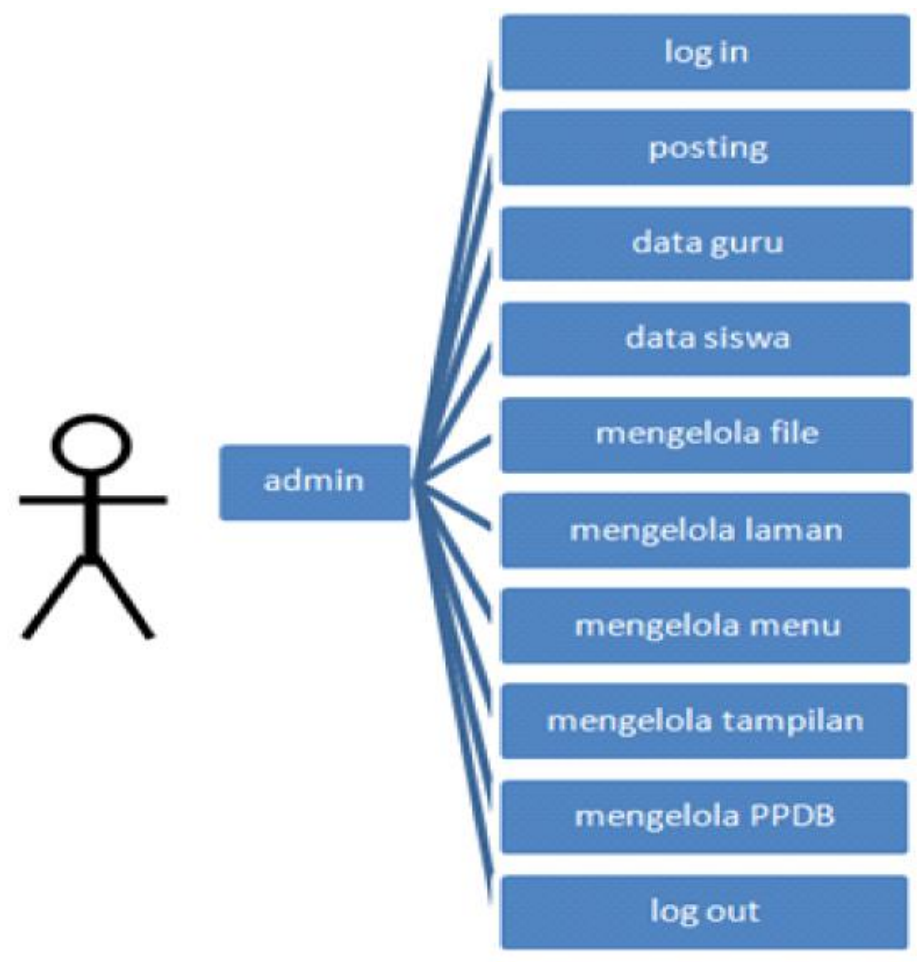

Gambar 3. Use Case Administrator

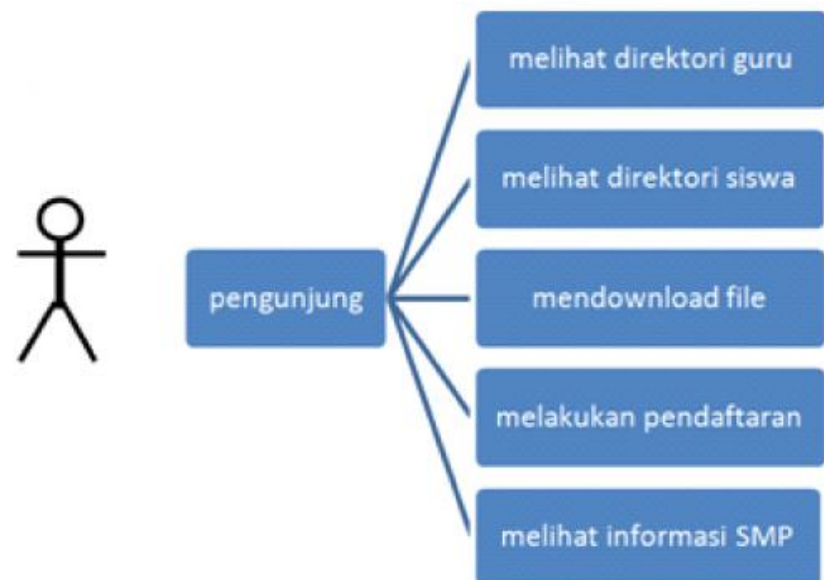

Gambar 4. Gambar Use Case Pengunjung

Website diimplementasikan dengan menggunakan bahasa pemrograman hypertext preprocessor (PHP) dan menggunakan code igniter (CI) sebagai framework. Pengelolaan databasenya menggunakan MySQL yang merupakan sebuah perangkat lunak sistem manajemen basis data structured query language (SQL) atau database management system (DBMS) yang multithread, multi-user, dengan sekitar 6 juta instalasi di seluruh dunia.

\section{HASIL DAN PEMBAHASAN}

Kegiatan pengabdian kepada masyarakat dilaksanakan di SMP Muhammadiyah 1 Kartasura dan SMA Muhammadiyah 4 Kartasura pada bulan September - Desember 2015. 
1. Template website yang dihasilkan

a. Website SMP Muhammadiyah 1 Kartasura

Website SMP Muhammadiyah 1 Kartasura sudah dionlinekan dan dapat diakses pada alamat: http:// smpmuh1kartasura.sch.id. Halaman pengguna umum merupakan halaman utama sistem informasi SMP Muhammadiyah 1 Kartasura yang dirancang sebagus mungkin agar dapat menarik perhatian pengunjung untuk melihatnya. Selain itu, informasi yang disajikan sesuai dengan apa yang menjadi tujuan dari pembuatan sistem ini. Halaman pengguna umum ini (dapat dilihat pada Gambar 5, terdiri dari beberapa bagian, diantaranya : menu yang meliputi Beranda, Profil, Galeri, Direktori, Prestasi, PPDB, Download, Galeri, Kontak.

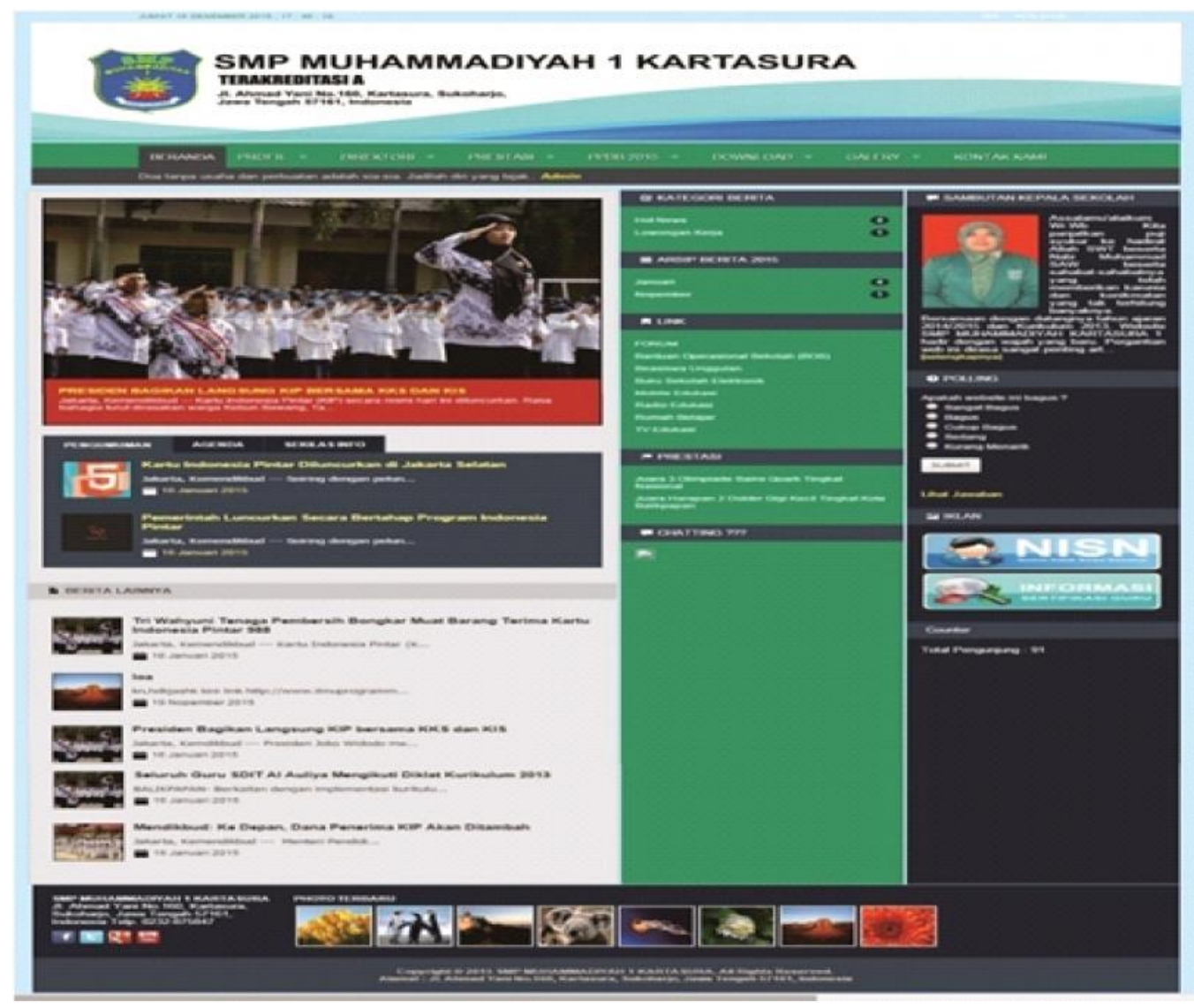

Gambar 5. Tampilan halaman utama website SMP Muhammadiyah 1 Kartasura

Pada menu profil ini terdapat beberapa informasi yaitu meliputi: sejarah berdiri, visi dan misi, struktur organisasi dan ekstrakurikuler. Pada menu Direktori terdapat tiga buah sub menu yaitu direktori guru, direktori siswa, dan direktori alumni. Menu prestasi akan menampilkan prestasi yang sudah diraih oleh sekolah, guru dan siswa. Menu penerimaan peserta didik baru (PPDB) adalah menu yang digunakan oleh siswa untuk mendaftarkan ke SMP Muhammadiyah 1 Kartasura secara online. Didalam menu PPDB terdapat sub menu daftar, download formulir, cetak formulir, hasil dan grafik seleksi. Menu Download berisi berbagai macam materi yang bisa 
didownload oleh para pengunjung umum yang meliputi materi pelajaran, materi ujian, dan tutorial atau tips. Menu Galeri berisi album photo yang bisi di lihat oleh semua anggota sekolah maupun umum, guru dan admin dapat membuat album dan mengunggah foto-foto, menu ini juga sebagai salah satu sarana dokumentasi. Menu kontak adalah menu yang menunjukkan alamat kontak sehingga warga sekolah dan umum dapat mengirimkan pesan saran dengan mengisi form yang di sediakan.
Untuk dapat mengakses semua menu yang ada dalam website ini, pengguna dengan hak akses administrator harus login terlebih dahulu sebagai admin dengan mengketikkan alamat : http:// smpmuh1kartasura.sch.id/login. kemudian setelah admin memasukkan username dan password maka akan muncul tampilan dashboard pada Gambar 6. Contoh tampilan pengaturan direktori guru dapat dilihat pada Gambar 7.

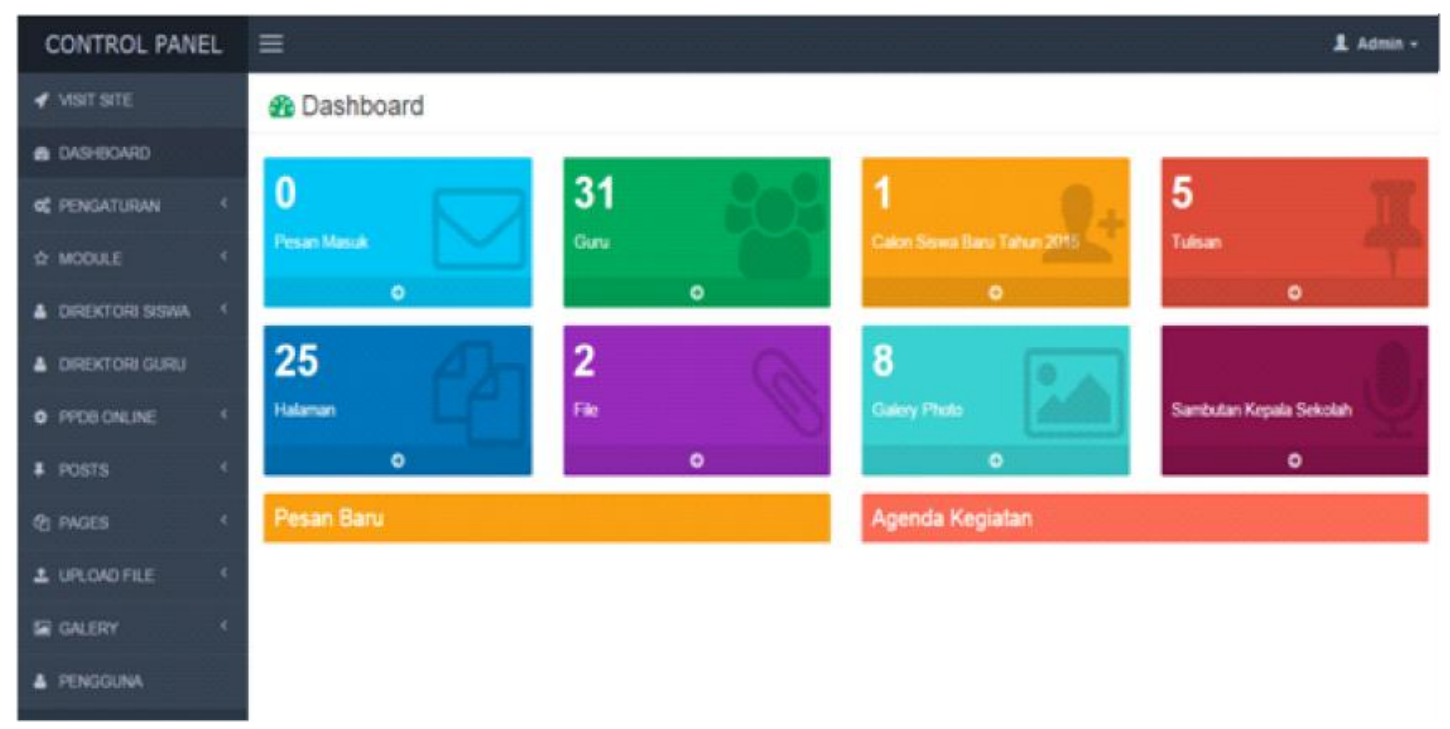

Gambar 6. Tampilan Dashboard

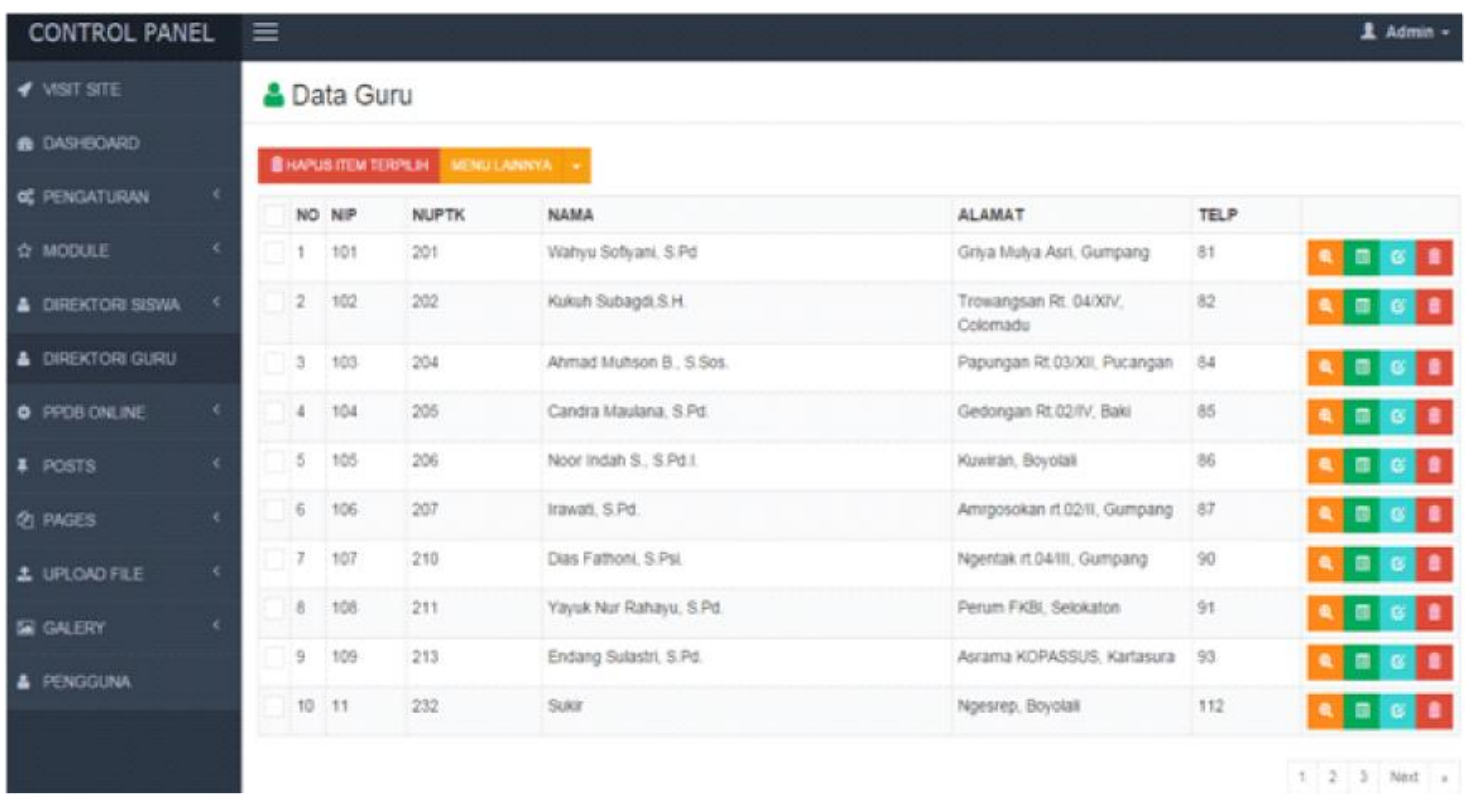

Gambar 7. Tampilan menu direktori guru 
b. Website SMA Muhammadiyah 4 Kartasura

Website SMA Muhammadiyah 4 Kartasura yang sudah dionlinekan dapat dilihat pada alamat www.smamuh4kartasura.sch.id.
Halaman utama pengunjung dibuat semenarik mungkin agar pengunjung nyaman. Berikut adalah implementasi halaman utama pengunjung pada Gambar 8 .

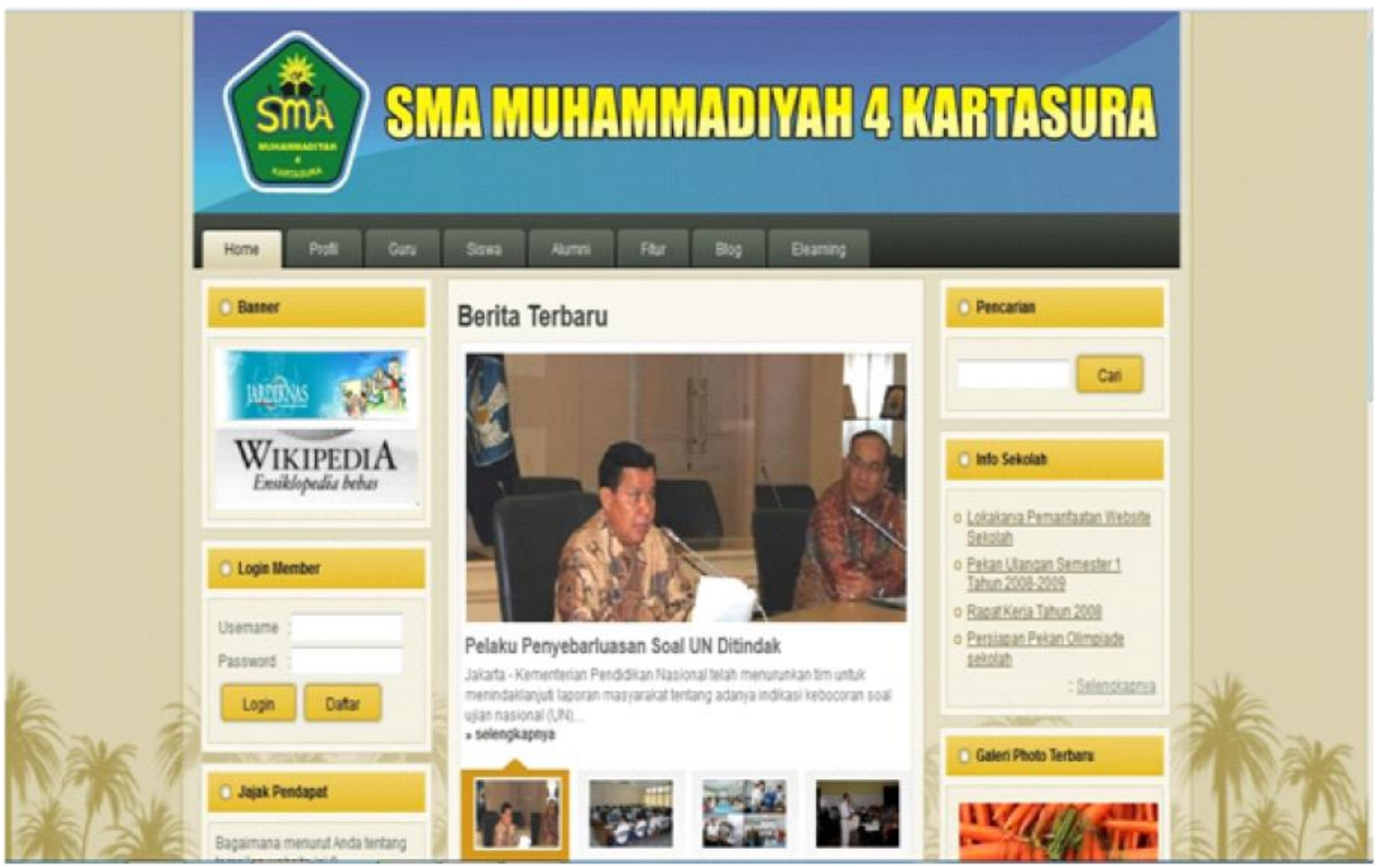

Gambar 8. Implementasi Halaman Utama Pengunjung

Pada halamn login admin dibuat tidak repot dan mudah digunakan cukup dengan mengisi username dan password.
Setelah berhasil masuk maka akan tampil halaman utama admin seperti pada Gambar 9. 


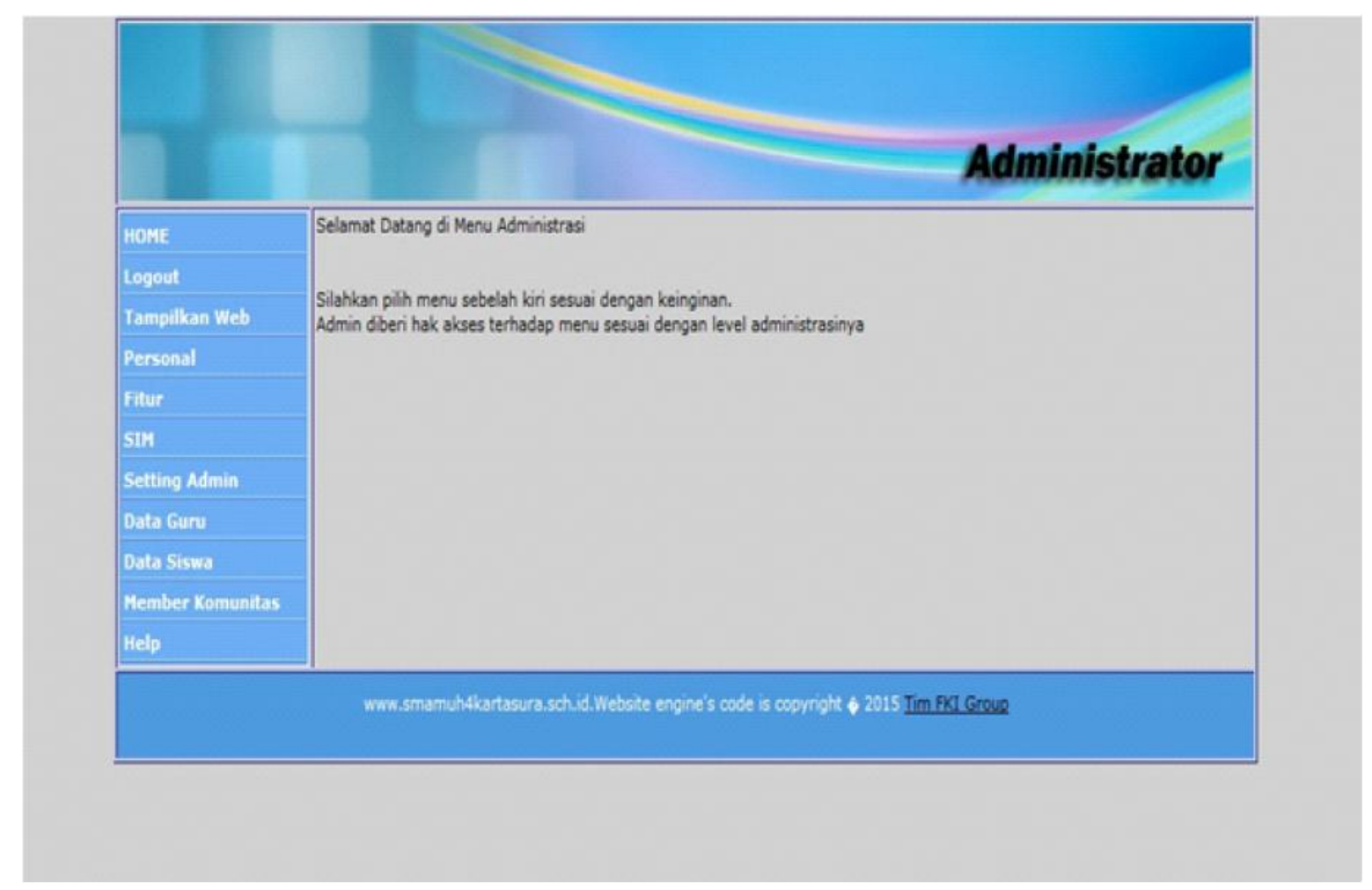

Gambar 9. Implementasi halaman utama admin

c. Evaluasi Pelaksanaan Kegiatan

Setelah pelaksanaan kegiatan selesai, tim pelaksana kegiatan pengabdian kepada masyarakat melakukan evaluasi keberhasilan pelaksanaan kegiatan dengan cara mengunjungi website kedua sekolah mitra dan melihat apakah website sekolah masih berjalan dengan baik dan apakah administrator pada kedua sekolah mitra sudah melakukan update pada konten web seperti yang sudah dilatihkan pada calon administrator pengelola. Hasil monitoring adalah guru sebagai admin sudah berhasil mengupdate konten website yaitu pada tanggal 16 Januari 2016 yang tampilannya seperti dapat dilihat pada Gambar 10. 


\section{KARTASURA}

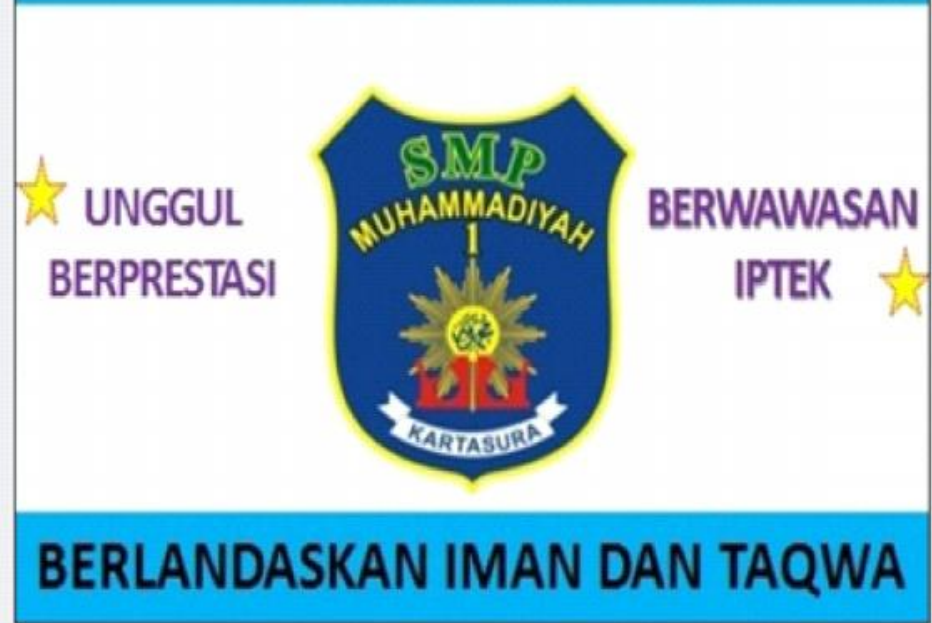

SMP Muhammadiyah 1 Kartasura is The Best

尚 16 Januari 2015 \& Admin

SMP Muhammadiyah 1 Kartasura Sekolah bernuansa Islami, unggul dalam prestasi berwawasan IPTEK dan berbudaya lingkungan. SMP Muhammadiyah 1 Kartasura merupakan sekolah ISLAM terpadu yang menggabungkan kurikulum umum dan kurikulum Islam. Di bawah bendera ORMAS Muhammadiyah, kami terus melaju pelan namun pasti untuk turut mencerdaskan anak bangsa. Allahu Akbar

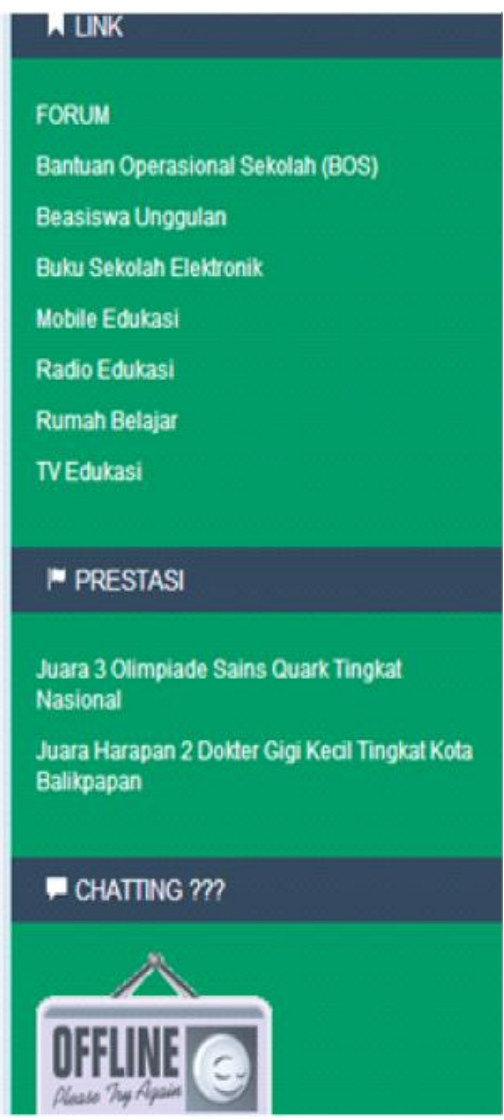

Gambar 10. Tampilan hasil update halaman bagian depan

\section{Pembahasan}

Website sekolah SMP Muhammadiyah 1 Kartasura dan SMA Muhammadiyah 4 Kartasura sudah diterapkan dan dionlinekan dengan menggunakan domain standar untuk sekolah di Indonesia yaitu dengan domain sch.id sesuai dengan kebutuhan masing-masing sekolah mitra. Website yang dibuat sudah menggunakan teknologi responsif sehingga memungkinkan untuk diakses dengan berbagai macam media dengan ukuran layar yang berbeda-beda seperti komputer, tablet dan smartphone. Perbandingan kondisi sebelum dan sesudah pelaksanaan pengabdian masyarakat dapat dilihat pada Tabel 1.
Beberapa kendala yang masih dihadapi dalam penerapan website disekolah mitra adalah: (1) diperlukan biaya untuk membayar biaya domain dan biaya hosting per tahun. Untuk SMA Muhammadiyah 4 Kartasura ini cukup membebani karena kondisi sekolah masih dalam tahap pertumbuhan, (2) di sekolah mitra belum ada karyawan atau guru yang berlatarbelakang pendidikan komputer atau informatika sehingga guru yang sudah dilatih belum memungkinkan untuk mengelola website dengan fitur dan fungsionalitas yang lebih canggih seperti sistem administrasi akademik dan sistem informasi pengelolaan keuangan berbasis komputer. 
Tabel 1. Perbandingan kondisi di sekolah mitra: sebelum pelaksanaan pengabdian kepada masyarakat dan sesudah pelaksanaan pengabdian kepada masyarakat.

\begin{tabular}{|c|c|c|}
\hline No. & $\begin{array}{c}\text { Kondisi Sebelum Pelaksanaan } \\
\text { Pengabdian }\end{array}$ & Kondisi Sesudah Pelaksanaan Pengabdian \\
\hline 1. & $\begin{array}{l}\text { Pada SMP Muhammadiyah } 1 \\
\text { Kartasura mempunyai website namun } \\
\text { berbasis blog yaitu } \\
\text { http://smpmutukartasura.blogspot.co } \\
\text { m. Website ini tidak sesuai dengan } \\
\text { standar website sekolah dan menunya } \\
\text { kurang representatif. }\end{array}$ & $\begin{array}{l}\text { Pada SMP Muhammadiyah 1 Kartasura sudah } \\
\text { mempunyai website dengan domain } \\
\text { standard pemerintah } \\
\text { http://smpmuh1kartasura.sch.id. Website yang } \\
\text { baru sudah mempunyai menu yang representatif } \\
\text { sebagai media pengenalan dan promosi SMP } \\
\text { Muhammadiyah 1 Kartasura. Website sekolah } \\
\text { dikelola oleh seorang guru yang ditunjuk yang } \\
\text { sudah dilatih untuk mengelola website. }\end{array}$ \\
\hline 2. & $\begin{array}{l}\text { SMP Muhammadiyah } 1 \text { Kartasura } \\
\text { belum mempunyai PPDB secara } \\
\text { online. }\end{array}$ & $\begin{array}{l}\text { Website yang baru sudah ada menu PPDB online } \\
\text { sehingga proses PPDB online bisa dilaksanakan. }\end{array}$ \\
\hline 3. & $\begin{array}{l}\text { SMA Muhammadiyah } 4 \text { Kartasura } \\
\text { sama sekali belum mempunyai } \\
\text { website sekolah. }\end{array}$ & $\begin{array}{l}\text { SMA Muhammadiyah } 4 \text { Kartasura sudah } \\
\text { mempunyai website yang sudah dionlinekan } \\
\text { dengan menggunakan domain yang standar } \\
\text { pemerintah yaitu www.smamuh4kartasura.sch.id. } \\
\text { Website ini dikelola oleh salah seorang guru yang } \\
\text { ditunjuk dan sudah dilatih untuk mengelola } \\
\text { website. }\end{array}$ \\
\hline 4. & $\begin{array}{l}\text { Pada dua sekolah mitra, promosi } \\
\text { hanya mengandalkan leaflet dan } \\
\text { spanduk yang jangkauannya terbatas }\end{array}$ & $\begin{array}{l}\text { Dengan mempunyai website yang sudah online } \\
\text { dengan menu yang representatif akan memberikan } \\
\text { keuntungan yang sifatnya intangible yaitu } \\
\text { meningkatnya prestise sekolah mitra dimata } \\
\text { masyarakat. Selain itu menu informasi dan prestasi } \\
\text { yang ada di website bisa diakses oleh masyarkat } \\
\text { termasuk calon siswa kapan pun dan dimanapun } \\
\text { selama masih ada sambungan internet. }\end{array}$ \\
\hline
\end{tabular}

\section{SIMPULAN DAN SARAN}

\section{Simpulan}

Dari kegiatan pelaksanaan pengabdian kepada massyarakat di SMP Muhammadiyah 1 Kartasura dan SMA Muhammadiyah 4 Kartasura, dapat ditarik kesimpulan sebagai berikut: (1) teknologi website untuk masing-masing sekolah mitra sudah berhasil dibuat dan digunakan dengan desain dan fitur menyesuaikan kebutuhan masing-masing sekolah mitra. Website sudah dionlinekan dengan nama domain sesuai dengan standar pemerintah yaitu untuk sekolah adalah sch.id, (2) website yang dibuat memberikan keuntungan yang bersifat intangible dan memungkinkan informasi dan prestasi sekolah bisa diakses oleh masyarakat kapan saja dimana saja selama ada jaringan internet tanpa terbatas jangkauan ruang dan waktu seperti layaknya promosi dengan menggunakan materian cetakan seperti leaflet atau spanduk.

\section{Saran}

Berdasarkan hasil pelaksanaan pengabdian dapat dirumuskan beberapa saran sebagai berikut: (1) website perlu diberi fitur atau menu yang lebih lanjut seperti sistem presensi dengan berbasis SMS gateway, (2) website perlu ditambahi dengan fitur sistem administrasi akademik 


\section{PERSANTUNAN}

Dengan terlaksananya kegiatan pengabdian kepada masyarakat ini tim pelaksana ingin mengucapkan terima kasih kepada Lembaga Penelitian dan Pengabdian kepada Masyarakat Universitas Muhammadiyah Surakarta (LPPM UMS) yang sudah menndukung kegiatan ini melalui skim pengabdian pada masyarakat kompetitif (PAKOM), Kepala Sekolah SMP Muhammadiyah 1 Kartasura dan SMA Muhammadiyah 4 Kartasura yang sudah bersedia menjadi mitra. Kegiatan pengabdian kepada masyarakat ini melibatkan mahasiswa sebagai berikut; Hamdani Nursyahid, Bryan Anthony Kurniawan, Irfan Nur Fahrudin, Donny Handoko, Imam Rivai, Dwi Cahyo Kurniawan (semuanya mahasiswa Program Studi Informatika FKI UMS) yang kemudian menggunakannya sebagai Praktek Kerja Nyata (PKN) sebagai salah satu mata kuliah di prodi Informatika FKI UMS.

\section{DAFTAR PUSTAKA}

http://smpmutukartasura.blogspot.com/

Graham, Lam S. 1995. HTML Source Book. Edisi Pertama. John Wiley \& Sons Inc, Canada.

Grannel, Craig; Sumner, Victor dan Synodinos, Dyonisios. 2011. The Essential Guide to HTML 5 and CSS3 Web Design. Appress Company.

Holzschlag, Molly E. 2004. 250 HTML and Web Design Secrets. Wiley Publishing, Inc., Indianapolis, Indiana

Willard, Wendy. 2010. Web Design: A Beginner's Guide Second Edition. McGraw-Hill, New York. 